\title{
PENERAPAN SISTEM INFORMASI MANAJEMEN TERHADAP BUDIDAYA IKAN GURAME DAN IKAN HIAS DESA SAMBIROBYONG
}

\author{
Shafa Aulia Shalsa Efendi, Vika Yanuarni, Lilis Mufidatun Na'imah \\ Email : Safasalsa312@gmail.com, lilismufida15@gmail.com, vyanuarni@gmial.com
}

\begin{abstract}
Abstrak
Penelitian ini bertujuan untuk mengetahui pemahaman tentang cara budidaya ikan gurame dan ikan hias dengan media kolam terpal, untuk mengetahui strategi pemasaran terhadap ikan gurami dan ikan hias, untuk mengetahui penjualan ikan gurami dan ikan hias, dan mengetahui cara penerapan sistem informasi manajemen terhadap budidaya ikan gurami dan ikan hias. Budidaya gurami dan ikan hias merupakan usaha yang dinilai mempunyai tingkat keuntungan yang lumayan besar. Dengan menggunakan sistem budidaya yang tepat, baik mulai dari modal, pembuatan kolam dan kapasitas tebar, penentuan benih, perawatan, penentuan harga jual, dan masa panen maka hasilnya akan maksimal. Fokus penelitian ini adalah, Bagaimanakah penerapan sistem informasi manajemen terhadap UMKM budidaya ikan gurami dan ikan hias desa Sambirobyong. Penelitian ini menggunakan pendekatan deskriptif kualitatif. Teknik pengumpulan data ini dengan cara wawancara di lapangan kepada informan. Dan hasil penelitian yang diperoleh adalah proses pembuatan kolam dengan media terpal adalah cara yang efektif dan efisien dibanding dengan kolam beton atau cor, pemberian air dan benih disesuaikan lebar kolamnya, strategi pemasaran dan penjualannya juga sudah bagus yaitu dengan menggunakan sistem informasi manajemen website.
\end{abstract}

Kata Kunci : Pemahaman, Budidaya Ikan Gurami dan Ikan Hias

\section{Abstract}

This study aims to determine the understanding of how to cultivate carp and ornamental fish with tarpaulin pond media, to determine marketing strategies for gouramy and ornamental fish, to determine the sales of gouramy and ornamental fish, and to know how to apply a management information system to carp cultivation. and ornamental fish. Cultivation of gouramy and ornamental fish is a business that is considered to have a fairly large level of profit. By using the right cultivation system, starting from capital, making ponds and stocking 
capacity, determining seeds, maintenance, determining selling prices, and harvesting times, the results will be maximized. The focus of this research is, How is the application of management information systems to SMEs in the cultivation of gouramy and ornamental fish in Sambirobyong village. This research use desciptive qualitative approach. This data collection technique is done by interviewing the informants in the field. And the research results obtained are the process of making ponds with tarpaulin media is an effective and efficient way compared to concrete or cast pools, the provision of water and seeds is adjusted to the width of the pool, marketing and sales strategies are also good, namely by using a website management information system.

Keywords: Understanding, Cultivation of Gourami and Ornamental Fish

\section{PENDAHULUAN}

Di negara Indonesia ini dikenal dengan negara maritim dan agraris, karena memiliki kekayaan sumber daya alam yang sangat melimpah. Indonesia mempunyai lautan yang lebih luas daripada daratan. Sehingga banyak masyrakat indonesia memanfaatkan sumber daya alam tersebut seperti pelaut atau nelayan yang tinggal di daerah laut, dan petani yang tinggal di darat. Salah satu kekayaan negara indonesia adalah di perikanan karena sumber daya perikanan di indonesia cukup besar, terutama dalam biodiversitas ikan. Dan bidang perikanan mempunyai peranan yang cukup penting, karena bergerak dalam sektor yang melestarikan hasil-hasil perikanan yang kaya akan protein dan sangat bermanfaat bagi masyarakan indonesia. (Yesserie, 2015)

Budidaya perikanan ikan adalah usaha atau kegiatan pemeliharaan dan perkembangbiakan ikan atau lainnya yang dilakukan oleh para peternak atau para petani. Budidaya ikan yang sangat diminati saat ini adalah seperti, ikan gurame, ikan lele, ikan patin, ikan nila, dan lain-lainnya. Dan ikan tersebut termasuk jenis budidaya ikan konsumsi karena jenis ikan tersebut dapat dikonsumsi sendiri atau pun dengan dijual bahkan diekspor ke negara-negara lain. 
Budidaya ikan yang tidak kalah dari budidaya ikan konsumsi adalah ikan hias. Yang sekarang ini di negara indonesia sangat melonjak di pasaran, sehingga banyak diminati oleh masyarakat. Ikan ini bukan untuk dikonsumsi melainkan hanya untuk memperindah atau hiasan. Seperti ikan cupang, ikan arwana, ikan gupi, ikan koki, dan lain-lain.

Budidaya ikan konsumsi yang sering di jumpai di desa saya adalah budidaya ikan gurami dan ikan lele, karena ikan tersebut cukup mengandung banyak gizi dan rasa ikan yang lebih lezat serta dapat diolah menjadi berbagai macam masakan yang sangat diminati juga.

Ikan gurami (Osphronemus gouramy) adalah salah satu varian ikan yang hidup di air tawar yang asli indonesia dan juga dibudidayakan serta dikonsumsi oleh masyarakat Indonesia karena rasa dagingnya yang lezat sehingga memperoleh nilai ekonomis yang tinggi, dan setiap tahunnya perkembangan ikan gurami ini mengalami peningkatanyang sangat tinggi. Bisa dilihat dari lingkungan hidupnya, ikan gurami ini hanya tahan hidup di kondisi air yang tergenang yang sedikit oksigen, dengan hal ini para petani ikan sangat memilih ikan gurami untuk dibudidaya daripada ikan lele atau lainnya. Saat ini, menurut catatan, indonesia memiliki lima daerah penghasil gurami terbesar, yaitu Jawa Barat, Jawa Tengah, Sumatera Barat, Jawa Timur, dan Nusa Tenggara Barat.

Ikan hias biasa dibudidaya di kolam atau di akuarium atau tergantung fungsi ikan tersebut. Ikan hias ini biasa hidup di air tawar dan cara budidaya nya juga hampir sama degan ikan gurami. Ikan hias ini biasa dipelihara sesuai dengan selera pasar dan harga pasar agar mendapatkan keuntungan yang maksimal. Budidaya ikan hias ini tidak mmebutuhkan lahan yang luas dan modalnya juga cukup ringan. Dan budidaya ikan hias ini hanya membutuhkan ketelatenan.

Budidaya ikan gurame dan ikan hias ini agar tetap terjaga stabilitasnya akan menggunakan sistem informasi untuk mendukung dan membuat kinerja 
dalam suatu usaha ajan terlaksana dengan baik dan dapat menangani berbagai kegiatan atau masalah serta solusi dengan menggunakan teknologi informasi.

Pesatnya perkembangan tekologi informasi selama beberapa tahun terkhur ini telah membawa dampak transformatif pada semua aspek kehidupan, termasuk dalam dunia bisnis dan informasi. Pertumbuhan internet telah berdampak pada perubahan cara organisasi, merancang, memproses, memproduksi, memasarkan, dan menyampaikan produk dan informasi. Sistem informasi ini dibuat untuk memudahkan bisnis dalam mengelola dan mengirimkan data untuk menghasilkan informasi yang benar-benar valid, akurat, dan meminimalkan kesalahan yang tidak perlu dan juga untuk meningkatkan efisiensi. Dan sistem informasi ini telah menghasilkan suatu perancangan website untuk memudahkan bagi yang ingin mengetahui informasi tentang budidaya ikan gurami dan ikan hias. (BARRIOS, 2014)

Penelitian ini bertujuan untuk mengetahui tentang pemahaman cara budidaya ikan gurame dan ikan hias dengan media kolam terpal, untuk mengetahui strategi pemasaran terhadap ikan gurame dan ikan hias, untuk mengetahui penjualan ikan gurame dan ikan hias, untuk mengetahui cara penerapan sistem informasi manajemen terhadap budidaya ikan gurame dan ikan.

Penelitian ini dibatasi pada penerapan sistem informasi manajemen budidaya ikan gurame dan ikan hias desa Sambirobyong.

\section{LANDASAN TEORI}

\section{DEFINISI SISTEM}

Soetarman mengatakan bahwa sistem adalah suatu kumpulan dari beberapa elemen yang saling berinteraksi dan berhubungan dalam satu sama lainnya untuk memdapatkan suatu tujuan agar mencapai hasil yang maksimal. (Admin, 2018)

\section{Ciri-Ciri Sistem}

Sistem mepunyai beberapa ciri-ciri yaitu, sebagai berikut: 

a. Adanya komponen sistem
b. Adanya batasan sistem
c. Adanya lingkungan luar sistem
d. Adanya penghubung sistem
e. Adanya masukan sistem

\section{Unsur-Unsur Sistem}

Sistem mempunyai beberapa unsur yaitu, sebagai berikut:

1. Obyek

2. Atribut

3. Hubungan Internal

4. Lingkungan

5. Tujuan

6. Masukan

7. Proses

8. Keluaran

9. Batas

\section{Jenis-Jenis Sistem}

Sistem mempunyai beberapa jenis yaitu sebagai berikut:

1. Jenis Sistem Berdasarkan Keterbukaan Jenis sistem ini ada 2, sistem terbuka dan tertutup.

2. Jenis Sistem Berdasarkan Komponen Jenis sistem ini ada 2, sistem fisik dan sistem non-fisik.

\section{Syarat-Syarat Sistem}

Sistem mempunyai beberapa syarat yaitu, sebagai berikut:

1. Sistem digunakan untuk mengatasi suatu masalah

2. Unsur sistem harus memiliki sebuah rencana

3. Ada hubungannya antar elemen

4. Elemen merupakan suatu proses yang terdiri dari informasi, energi dan aliran yang lebih penting daripada elemen sistem 
5. Tujuan organisasi lebih penting daripada tujuan

\section{DEFINISI INFORMASI}

Menurut Raymond McLeod, informasi adalah data yang sudah diolah menjadi bentuk baru yang mempunyai makna valid dan bermanfaat untuk suatu keputusan. (Putra, 2009)

\section{Jenis-Jenis Informasi}

Informasi mempunyai beberapa jenis yaitu, sebagai berikut:

1. Berdasarkan Fungsi Dan Kegunaan

lnformasi tersebut dapat menambahkan wawasan dan juga memberikan panduan.

2. Berdasarkan Format Penyajian

lnformasi tersebut berupa bentuk teks, gambar (foto), dan juga video (film)

3. Berdasarkan Aspek

Informasi ini bisa berupa aspek ekonomi, pendidikan, kesehatan, gaya hidup, politik, dll

4. Berdasarkan Cara Penyampaian Informasi ini dapat disampaikan setiap apapun waktunya

\section{Fungsi Informasi}

Informasi mempunyai beberapa fungsi yaitu:

1. Menciptakan sumber pengetahuan baru

2. Menghapus Kepalsuan

3. Untuk Media Hiburan

4. Sebagai Sumber Berita

5. Untuk Sosialisasi Kebijakan

6. Untuk Mempengaruhi Khalayak

7. Mempersatukan Opini 


\section{DEFINISI SISTEM INFORMASI}

Menurut La Midjan dan Susanto, sistem informasi merupakan elemenelemen yang berkaitan satu sama lain dan bekerjasama guna mengumpulkan, memproses, menyimpan, dan mendistribusikan informasi untuk mendukung pengambilan suatu keputusan, koordinasi, dan manajemen serta untuk di dalam menguraikan aktivitas internal kita. (Sidh, 1975)

\section{Tujuan Sistem Informasi}

Sistem lnformasi mempunyai tujuan yaitu untuk mendapatkan sebuah informasi. Dan informasi tersebut harus valid serta memberikan keuntungan bagi penggunanya. Ada tiga pondasi untuk sistem informasi yaitu harus relevance (hubungan), timeliness (ketepatan waktu), accurate (tepat).

\section{Fungsi Sistem Informasi}

Sistem informasi mempunyai tujuan seperti:

a. Meningkatkan aksebilitas data pengguna secara efektif dan efisien

b. Memastikan ketersediaan kualitas dan keterampilan dalam penggunaan kritis sistem informasi

c. Meningkatkan produktivitas pengembangan aplikasi dan pemeliharaan sistem.

d. Mengembangkan proses perencanaan yang efektif.

\section{Komponen Sistem Informasi}

Beberapa komponen sistem informasi adalah, komponen input, output, model, tehnologi, basic data, dan control.

\section{Ciri-Ciri Sistem Informasi}

Ciri-ciri sistem informasi adalah:

1. Baru

2. Tambahan

3. Kolektif

4. Penegas 


\section{DEFINISI SISTEM LNFORMASI MANAJEMEN}

Menurut Raymond dan Goerge, sistem informasi manajemen adalah suatu sistem komputerisasi dan pembuat informasi valid untuk penggunanya yang membutuhkannya. Informasi ini terutama menggambarkan suatu perusahaan atau salah satu sistemnya tentang apa yang telah terjadi di masa lalu, sekarang dan akan datang. Informasi ini berupa laporan reguler, laporan khusus, dan hasil dari simulasi matematika. (Fionita \& Magdalena, 2015)

Menurut Susanto, sistem informasi manajemen saling berhubungan, dan berfungsi secara harmonis atau sinkron untuk mencapai tujuan yang sama, yaitu subbab sistem yang mengolah data menjadi informasi yang dibutuhkan manajemen untuk mengambil keputusannya dalam proses keputusan . (Sidh, 1975)

Dari beberapa penjelasan diatas dapat disimpulkan bahwa sistem informasi manajemen adalah sistem informasi yang tidak hanya memproses semua transaksi yang diperlukan oleh suatu organisasi (usaha), tetapi juga menyediakan dukungan informasi dan dukungan pemrosesan untuk operasi bisnis dan pengambilan keputusan.

\section{Komponen Sistem Informasi Manajemen}

Komponen sistem informasi adalah:

1. Perangkat output

Perangkat output merupakan komponen komputer yang bisa diraba, dilihat dengan mata dan bersentuhan dengan tangan.

2. Perangkat software

Perangkat software ini kebalikan dari perangkat output yaitu komponen komputer yang tidak bisa diraba, dan dilihat secara fisik.

3. Data base

Database ini berfungsi untuk tempat penyimpanan data dan informasi dari beberapa unit organusasi.

4. Prosedur pengoperasian 
Prosedur ini berupa rangkaian aktivitas yang dilakukan secara berkali-kali dan juga dengan cara yang sepadan.

5. Jaringan komputer dan komuniaksi data

\section{METODE PENEIITIAN}

Penelitian ini merupakan penelitian kualitatif artinya prosedur pencatatannya menggunakan atau menggambarkan keadaan objek yang diteliti berdasarkan fakta yang ada. Methode kualitatif sering disebut sebagai methode alternatif. Methode ini tidak meakai pertanyaan yang detail tetapi diawali dengan pertanyaan umum dan semakin keintinya. (Kaleb, 2019)

\section{TEMPAT DAN WAKTU PENELITIAN}

Penelitian ini dilakukan di Desa Sambirobyong dirumah bapak Gufron. Beliau adalah pemilik budidaya ikan gurame dan ikan hias.

\section{TEKNIK PENGUMPULAN DATA}

Pengumpulan data untuk penelitian ini dengan cara berwawancara di lapangan kepada informan penelitian.

\section{TEKNIK ANALISIS DATA}

Analisis data untuk penelitian ini memakai analisis deskriptif kualitatif merupakan yang cara pencatatannya menggunakan atau melukiskan kondisi suatu obyek yang diamati bersumber dari kenyataan.

\section{PEMBAHASAN}

Ikan gurami (Osphronemus gouramy) adalah salah satu varian ikan yang hidup di air tawar yang asli indonesia dan juga banyak dibudidayakan serta dikonsumsi oleh masyarakat Indonesia. Dan juga ikan hias merupakan varian ikan yang hidup di air tawar ataupun di air asin dan dipelihara hanya untuk digunakan hiasan atau pun dijual. Ikan gurame dan ikan hias tersebut masuk dipasaran dengan harga yang lumayan tinggi dan juga biasa dikirim sampai ke luar pulau bahkan luar negara juga.

Pada umumnya ikan gurami dan ikan hias dibudidaya dikolam terpal dengan hal ini semakin diminati oleh mayarakat karena tidak membutuhkan 
lahan yang luas serta sumber air yang minim. Bila awalnya dalam membudidayakan ikan gurami dan ikan hias dilakukan di empeng maupun dikolam yang terdapat aliran air, saat ini ikan gurami dan ikan bisa dibudidayakan di kolam terpal. Jika menggunakan kolam terpal kita akan mudah membongkarnya jika tidak dipakai lagi.

\section{TAHAP CARA BUDIDAYA IKAN DENGAN MENGGUNAKAN TERPAL PADA KOLAM}

Berikut tahapan cara membudidaya ikangurami maupun ikan hias di kolam terpal yang baik dan benar sehingga pada metode ini bisa mendapatkan keuntungan yang maksimal.

\section{Proses Membuat Media Kolam}

Untuk bahan yang akan dipakai untuk membuat kolam adalah plastik dan terpal, terpal tersebut bisa didapatkan di toko pertanian ataupun toko khusus terpal. Jika tidak ingin memakai terpal boleh menggantinya dengan plastik yang berwarna hitam dan panjang yang bisa didapatkan di toko pertanian atau toko plastik. Sementara itu kolam terpal juga membutuhkan batu bata merah atau dengan tanah lalu dikasih batako untuk sebagai bantalan dinding dengan tinggi maksimum panjang 4 meter, lebar 2 meter, dan tinggi 1 meter. Langkah pertama adalah membuat dinding dari batu bata merah setelah terpasang dengan benar, kemudian pasangkan terpal atau plastik pada dinding dalam dan dasar kolam.

\section{Cara Mengisi Air Kolam}

Langkah seterusnya adalah dengan pengisian kolam dengan dengan tinggi sama dengan kolam atau disisakan $10 \mathrm{~cm}$. Hal ini bertujuan agar jika waktu hujan atau lainnya ikan dibisa melompat keluar. Dan jika kolam masih baru sebaiknya kolam tersebut jangan langsung diberi ikan tetapi didiamkan sekitar satu mingguan. Agar air tersebut bisa adaptasi di kolam. 


\section{TAKARAN JUMLAH BENIH}

Dengan ukuran kolam diatas dapat diisi oleh kurang lebih 250 ekor, agar ikan-ikan tersebut bisa mengalami pertumbuhan yang maksimal. Karena biasanya kolam yang diisi terlalu banyak ikan, ikannya akan mati.

Jika kolam tersebut sudah diisi ikan maka harus rajin memberinya pakan. Waktu untuk memberi pakan adalah di pagi dan sore. Dan untuk menghindari dari sinar matahari langsung kita bisa memberikan beberapa daun enceng gondok, daun tersebut berfungsi untuk menjaga suhu air agar tetap stabil. Dan daun enceng . dan dalam perawatan kolam tersebut harus rutin dibersihakan setiap tiga hari sekali atau satu minggu sekali agar ikannya terus mendapatkan oksigen yang baik. Dan boleh juga ditambahkan sanitizer untuk mencegah ikan terkena penyakit.

Proses- proses ini semua jika kita lakukan dengan benar maka budidaya ikan gurame ataupun ikan hias dikolam terpal akan mendapatkan hasil yang maksimal. Dan masa ikan gurame panen adalah sekitar 5 bulanan, dan pada bulan itu gurame siap panen dan siap dikirim ke pengepul lain bahkan di luar kota.

\section{STRATEGI PEMASARAN USAHA BUDIDAYA IKAN}

Strategi ini sangat dibutuhkan oleh suatu kelompok usaha untuk dihubungkan dengan lingkunnya karena lingkungan tersebut bisa memberikan dampak positif terhadap usaha kita, dan strategipun juga harus dipilih sesuai kebutuhannya.(Gesah \& Prabowo, 2019)

1. Segmentasi dan Target Budidaya Ikan

Pada saat sesi wawancara kepada pemilik usaha ikan gurami dan ikan hias tersebut, beliau menyatakan bahwa segmentasi pasar untuk jenis ikan gurami dan ikan hias ini adalah untuk rumah-rumah, masyarakat umum dan pembudidaya ikan lainnya disekitar desa 
Sambirobyong, Purworejo, Bendiljati Wetan, dan beberapa desa lainnya. Dan ikan-ikan tersebut harus yang berkualitas, sehat, dan lain-lain agar tidak mengecewakan pasaran atau konsumen.

Kata pak Gufron sebagai petani ikan, "kami juga menawarkan beberapa tips merawat ikan dan kolam agar awet dan baik untuk ikan kepada pelanggan lama. Dengan hal itu para pelanggan akan puas dan tertarik untuk berlangganan. (Arwi, 2020)

2. Perawatan dan Lokasi

- Pemilihan lokasi yang pas (terkena sinar matahari)

- Pemilihan bibit ikan yang sehat

- Pemberian pakan yang sesuai

- Pengeringan kolam setelah panen dan sebelum pemasukan benih.

3. Produk Usaha

Produk usaha (ikan) yang dijual lebih mementingkan ikan gurami atau ikan hias yang sudah siap panen akan tetapi jika ada konsumen yang mencari ikan yang belum siap panen pemilik usaha ini juga akan menjual dan menawarkan berbagai macam ikan mulai dari yang benih sampai yang siap panen. Dan ada bermacam-macam paket harga sesuai yang diinginkan oleh konsumen. Paket tersebut terdiri dari yang Rp. 200 setiap ekornya untuk ukuran (1-3 cm), Rp. 1000 untuk ukuran $(8-9 \mathrm{~cm})$, dan untuk yang siap panen ukuran 7-9 ons juga bisa mencapai Rp. 35.000 per kilonya dan untuk ikan hias siap dipanen maka warna ikan akan berubah, dari hitam menjadi hijau dan bisa berganti 3 warna setiap ekornya dan harganya bisa mencapai Rp. 500.000 per ekor, tetapi jika ikan hiasnya kurang bagus harganya juga sangat anjlok mungkin harga jualnya hanya sampai Rp. 2.000 per ekor.

\section{STRATEGI PENJUALAN}


Produk ikan yang sudah siap jual akan dijual kepada pedagang gurami ke pengepul dan akan dikembalikan ke petani lagi untuk dipelihara lagi. Harga satu kg nya bisa sampai Rp. 35.000 .

Data hasil penjualan per tahun 2020

\begin{tabular}{|l|l|l|l|l|l|}
\hline No. & Bulan & Jumlah & $\begin{array}{r}\text { Nama } \\
\text { Barang }\end{array}$ & $\begin{array}{l}\text { Harga } \\
\text { Barang }\end{array}$ & $\begin{array}{l}\text { Harga } \\
\text { Total }\end{array}$ \\
\hline 1 & Maret & 3,5 ton & Ikan Gurami & Rp. 26.000 & Rp. 91.000.000 \\
\hline 2 & Mei & 3 ton & Ikan Gurami & Rp. 22.000 & Rp. 66.000.000 \\
\hline 3 & Juli & 2,5 ton & Ikan Gurami & Rp. 24.000 & Rp.60.000.000 \\
\hline 4 & Desember & 3 ton & Ikan Gurami & Rp. 27.000 & Rp. 81.000.000 \\
\hline
\end{tabular}

Data hasil penjualan per tahun 2021

\begin{tabular}{|c|c|c|c|c|c|}
\hline No. & Bulan & Jumlah & $\begin{array}{c}\text { Nama } \\
\text { Barang }\end{array}$ & $\begin{array}{c}\text { Harga } \\
\text { Barang }\end{array}$ & $\begin{array}{c}\text { Harga } \\
\text { Total }\end{array}$ \\
\hline 1 & April & 2,5 ton & Ikan Gurami & Rp. 28.000 & Rp. 70.000.000 \\
\hline 2 & Juni & 3 ton & Ikan Gurami & Rp. 28.000 & Rp. 84.000.000 \\
\hline 3 & Oktober & 3 ton & Ikan Gurami & Rp. 29.000 & Rp. 87.000.000 \\
\hline 4 & November & 3 ton & Ikan Gurami & Rp. 31.000 & Rp. 93.000.000 \\
\hline
\end{tabular}

Seluruh kolam yang dipakai dalam budidaya ikan gurame ini ada 5 tempat dan untuk budidaya ikan hiasnya juga ada 5 tempat. Dan petani Gufron sendiri yang mengelola mulai dari memberi makan, membersihkan kolam, dan mengecek ikan, serta lain-lainnya.

Berikut adalah gambar kolam dan ikan gurame milik petani ikan Bapak Gufron: 

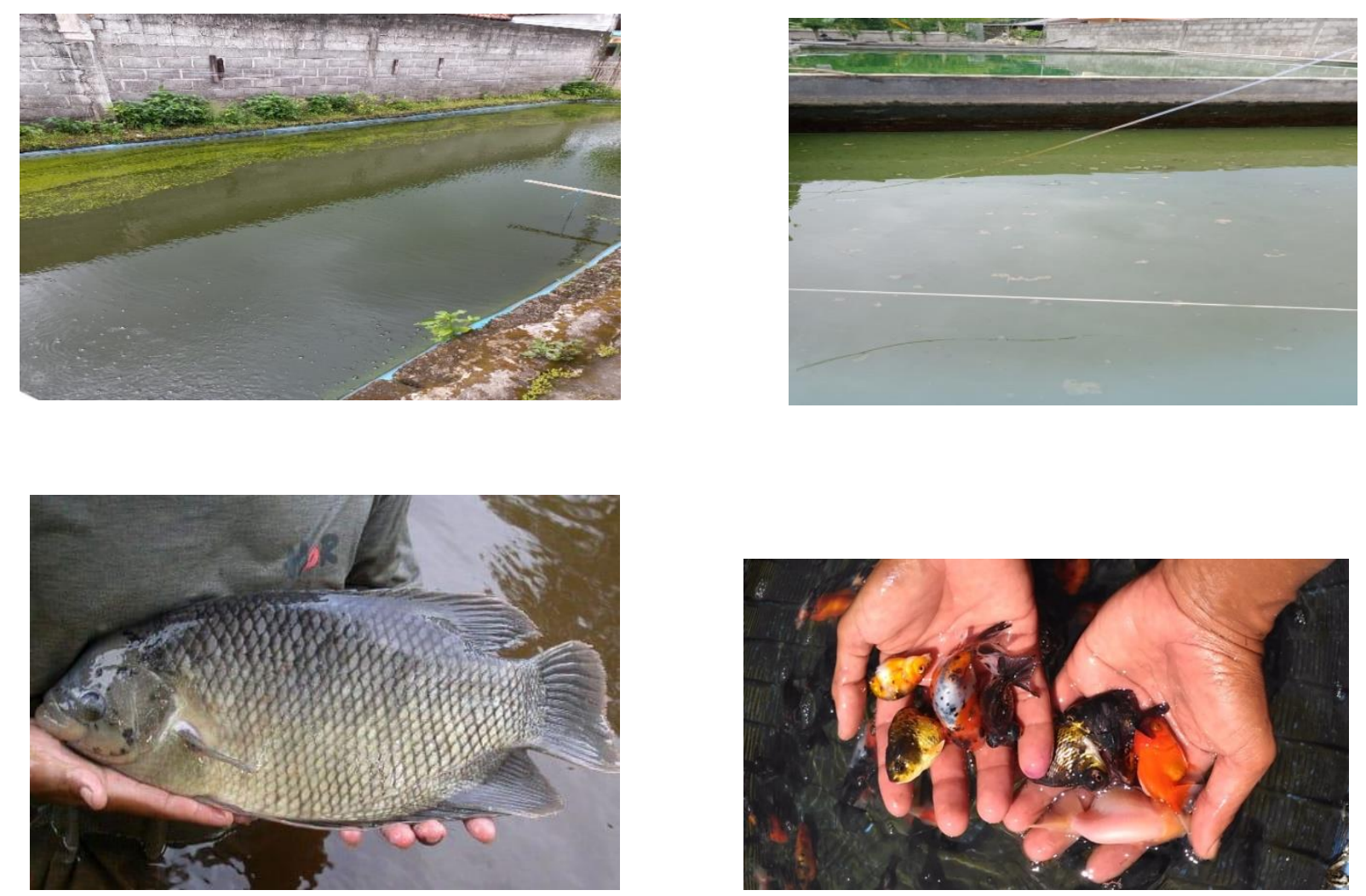

\section{PENERAPAN SISTEM INFORMASI BUDIDAYA IKAN GURAMI}

Penerapan dan perkembangan sistem informasi pada budidaya ikan gurami sangat pesat apalagi pada budidaya ikan hias. Pada mulanya ikan hias juga sangat pesat menjadi pusat perhatian dan publik figur mayarakat bukan hanya mayarakat daerah tulungagung tetapi ikan hias menjadi daya tarik warga luar Jawa Timur. Dalam sehari ribuan ikan hias akan terjual habis. Tidak hanya itu ikan gurami juga sangat menjadi pusat daya tarik warga. Karena ikan gurami sangat dibutuhkan oleh restoran besar, sehingga petani ikan gurami budidaya ikan gurami pada setiap kolam berisikan kurang lebih 1.000 sesuai kondisi dan lokai kolam besar atau tidaknya. (Infomania, 2021)

Sistem informasi budidaya ikan gurami dan ikan hias berbasis web yang berada di desa sambirobyong, sumbergempol merupakan sebuah sistem untuk mengelola data budidaya penjualan ikan gurami dan ikan hias, mengelola laporan penjualan dan memberikan informasi yang bertujuan untuk memudahkan dalam memberikan informsai budidaya penjualan ikan gurami dan ikan hias. Pada awalnya petani ikan ini melakukan pencatatan,perhitungan dan 
transaksi penjualan dan laporan penjualan masih menggunakan sistem manual. Oleh karena itu pencatatan,perhitungan dan laporan penjualan menjadi kurang efektif dan efisien. Dengan menggunakan website sebagai media promosi dan alat bantu mengolah data budidaya penjualan ikan gurami dan ikan hias dan data laporan penjualan dengan cara yang lebih mudah dan efisien. Adapun langkah-langkah yang digunakan untuk memperoleh data dan informasi yang menunjang pelaksanaan penelitian ini adalah obeservasi dan wawancara.

Metode yang digunakan dalam pembuatan aplikasi website ini menggunakan metode waterfall yang dimulai dari analsis, desain, kode, pengujian dan pemeliharaan. Sistem informasi budidaya ikan gurami dan lele berbasis web berperan penting untuk meningkatkan informasi budidaya penjualan ikan gurami dan ikan hias, sehingga memudahkan dalam mengolah data budidaya penjualan ikan gurami dan ikan hias dan data laporan penjualan.

\section{KESIMPULAN}

Berdasarkan hasil penelitian yang kami lakukan mengenai Peran Sistem Informasi Manajemen Terhadap Budidaya Ikan Gurami dan Ikan Hias Desa Sambirobyong yang beralamat di Dusun Sambigede, Rt. 003/Rw. 006, Desa. Sambirobyong, Kec. Sumbergempol, Kab. Tulungagung dapat di simpulkan bahwa :

1. Penggunaan kolam terpal tidak seenaknya saja karena ada tahapan yang baik dan benar dalam penggunaan metode ini. Pertama, dengan membuat media kolam. Kedua, teknik pengisian air kolam. Ketiga, takaran jumlah benih ikan yang akan dimasukkan ke dalam kolam

2. Strategi pemasaran budidaya ikan

Dengan memilih bibit ikan yang berkualitas, pemilihan lokasi yang strategis, memberi pakan dan protein nabati secara teratur, membersihkan kolam setelah ikan di panen dan mengeringkan kolam sebelum pembudidayaan agar ikan tidak terkena penyakit.

3. Strategi penjualan 
Pada sistem ini petani per kilonya petani bisa mematok harga Rp. 35.000 karena harga setiap tahunnya naik turun sehingga petani juga harus pandai memilih pedagang dalam menjual ikannya.

4. Penerapan sistem informasi dalam budidaya ikan

Pada budidaya ini petani mengambil 2 sistem yaitu sistem manual dan berbasis web karena awal mula petani menggunakan sistem manual dalam pencatatan, perhitungan, transaksi penjualan dan laporan penjualan akan tetapi dengan seiringnya teknologi yang semakin canggih petani juga menggunakan website sebagai media promosi dan alat bantu untuk mengolah data budidaya ikan gurami dan hias.

\section{SARAN}

Dari kesimpulan diatas, dapat diperoleh beberapa saran atau harapan yaitu sebagai berikut:

1. Untuk peneliti peneliti lain diharapkan bisa meneliti secara spesifik dan lebih mendalami lagi tentang budidaya ikan gurami dan ikan hias dan mendalami tingkat permasalahan yang ada agar usaha tersebut semakin maju dan sukses.

2. Untuk petani petani ikan lainnya yang budidaya ikan gurami dan ikan hias sebagusnya bisa mempelajari teknologi-teknologi atau media sosial seperti facebook, instagram, ataupun web-web yang sudah disediakan, agar usahanya bisa lebih berkembang pesat dan diketahui banyak orang, dan bisa bertransaksi dengan mudah tidak ribet, dan pengiriman untuk luar kota sudah dijamin aman.

\section{DAFTAR PUSTAKA}

Admin. (2018). Konsep Dasar dan Pengertian Sistem. In Universitas Negeri Padang (p. 2018). http://bpakhm.unp.ac.id/konsep-dasar-dan-pengertiansistem/

Arwi, M. N. (2020). BUDIDAYA IKAN GURAMI ( Studi Kasus Usaha Budidaya Ikan Gurami “ Ar i fin Ikan ” Di Dusun Nusawaru Desa Jatijajar 
Kecamatan Ayah Kabupaten Kebumen ). 32.

BARRIOS, J. P. R. M. B. (2014). budidaya ikan gurame. Journal Article, 97.

Fionita, I., \& Magdalena, B. (2015). Penerapan Sistem Informasi Manajemen Pada Usaha Kecil Menengah Di Provinsi Lampung. Jurnal Bisnis Darmajaya, 1(2), 98-107.

Gesah, R., \& Prabowo, M. (2019). Manajemen Strategi Penulis: Rachmad Gesah Mukti Prabowo. INA-Rxiv Paper.

Infomania. (2021). [INFOMINA] Cara Budidaya Ikan Gurame Di Kolam Terpal. Infomania.

Kaleb, B. J. (2019). Penerapan Sistem Informasi Manajemen Dan Pengawasannya Di Kantor Pelayanan Pajak Pratama Manado. Jurnal EMBA: Jurnal Riset Ekonomi, Manajemen, Bisnis Dan Akuntansi, 7(1), 781-790. https://doi.org/10.35794/emba.v7i1.22555

Putra. (2009). Pengertian Informasi: Fungsi, Konsep Dasar \& Jenis Jenisnya Salamadian (p. 1). https://salamadian.com/pengertian-informasi/

Sidh, R. (1975). peranan brainware dalam sistem informasi manajemen. Jurnal Computech Dan Bisnis, 23(4), 795-798. https://doi.org/10.1021/jf60200a019

Yesserie. (2015). pengaruh pemberian pakan buatan menggunakan limbah kepala udang dengan dosis berbeda terhadap pertumbuhan dan sintasan benih ikan gurame. Ekonomi, 151, 10-17. https://doi.org/10.1145/3132847.3132886 